DOI: https://doi.org/10.24127/ajpm.v10i2.3365

\title{
ANALISIS KEMAMPUAN REPRESENTASI MATEMATIS MATERI PERSAMAAN LINEAR DUA VARIABEL
}

\author{
Rohana $^{1}$, Eka Fitri Puspa Sari ${ }^{2 *}$, Siti Nurfeti $^{3}$ \\ ${ }^{1,2 * 3}$ Universitas PGRI Palembang, Palembang, Indonesia \\ *Corresponding author. \\ E-mail: $\underline{\text { rohana@univpgri-palembang.ac.id }}^{1)}$ \\ ekafitrips@univpgri-palembang.ac.id $^{2 *}$ \\ sitinurfeti11@gmail.com $^{3)}$
}

Received 08 December 2020; Received in revised form 25 June 2021; Accepted 28 June 2021

\begin{abstract}
Abstrak
Penelitian ini bertujuan untuk mengetahui kategori kemampuan representasi matematis peserta didik. Metode yang digunakan yaitu metode analisis deskriptif. Subjek penelitian ini adalah peserta didik kelas IX.2 SMP Negeri 16 Palembang Tahun Ajaran 2019/2020 sebanyak 30 orang. Teknik pengumpulan data yang digunakan adalah tes, wawancara dan dokumentasi. Instrumen tes berupa 4 soal uraian materi sistem persamaan linear dua variabel. Teknik analisis data dalam penelitian ini menggunakan statistik deskriptif. Hasil penelitian menunjukkan bahwa pada representasi visual memiliki persentase rata-rata sebesar 43,33 dengan sebagian besar peserta didik belum mampu menentukan titik potong dan menggambarkan titik potong pada koordinat kartesius. Indikator representasi ekpresi matematis sebesar 80,37 menunjukkan bahwa peserta didik mampu menyelesaikan permasalahan menggunakan representasi ekpresi matematis tetapi sebagian besar peserta didik keliru dalam menentukan solusi terakhir. Indikator representasi katakata atau teks tertulis sebesar 28,89 dengan sebagian besar peserta didik belum mampu menyatakan strategi penyelesaian menggunakan kata-kata atau teks tertulis. Secara keseluruhan didapat persentase rata-rata kemampuan representasi peserta didik sebesar 62,66 dengan kategori sedang.
\end{abstract}

Kata kunci: Analisis deskriptif; kemampuan representasi matematis; sistem persamaan linear dua variabel.

\begin{abstract}
The purpose of this study were to determine the category of mathematical representation ability of students. The method used is descriptive analysis method. The subjects of this study were 30 students of class IX.2 SMP Negeri 16 Palembang on 2019/2020 academic year. Data collection techniques used are tests, interviews and documentation. The test instrument consists of 4 questions about the material description of a two-variable linear equation system. The data analysis technique in this study used descriptive statistics. The results showed that the visual representation had an average percentage of 43.33 with most of the students not being able to determine the intersection point and describe the intersection point at the Cartesian coordinates. The mathematical expression representation indicator of 80.37 shows that students are able to solve problems using mathematical expression representations but most of the students are wrong in determining the final solution. The indicator for the representation of words or written text is 28.89 with most of the students not being able to state the settlement strategy using written words or text. Relativity, student's representation ability was 62.66 in the moderate category.
\end{abstract}

Keywords: Descriptive analysis; mathematical representation ability; two variable linear equation system. 


\section{PENDAHULUAN}

Tujuan matematika berdasarkan kurikulum 2006 yang disempurnakan pada kurikulum 2013 yaitu: 1) memahami konsep matematika, 2) meningkatkan kemampuan penalaran peserta didik berdasarkan konsep matematika, 3) memecahkan masalah, 4) melatih kemampuan komunikasi peserta didik, dan 5) mengembangkan minat dan rasa ingin tahu peserta didik terhadap matematika serta meningkatkan sikap ulet dan percaya diri dalam memecahkan masalah (Latif \& Akib, 2016). Berdasarkan tujuan pembelajaran matematika yang telah diuraikan, terdapat suatu kemampuan yang dapat menunjang ketercapaian tujuan tersebut. Sebagaimana Wijayanti dan Deniyanti (2020) menyatakan bahwa kemampuan representasi merupakan penunjang untuk kemampuan komunikasi, pemahaman, pemecahan masalah, dan penalaran.

\section{Kemampuan} representasi matematis merupakan dasar atau fondasi bagi seorang peserta didik untuk memahami dan menggunakan ide-ide matematika dalam menyelesaikan permasalahan matematis (Sari \& Sari, 2019). Ide-ide atau gagasan tersebut diinterpretasikan kedalam bentuk grafik, gambar, simbol-simbol atau tulisan matematis sebagaimana dinyatakan oleh Pasehah dan Firmansyah, (2019). Hal tersebut sejalan dengan pendapat Kurniawan dan Kartono (2018) yang menyatakan bahwa kemampuan representasi matematis adalah bentuk interpretasi kemampuan siswa terhadap suatu masalah yang dihadapi, dimana untuk menemukan solusi permasalahan yang dihadapi peserta didik menggunakan interpretasinya sebagai alat bantu.

Jika setiap peserta didik mempunyai kemampuan representasi, besar kemungkinan akan mampu menyelesaikan permasalahan matematika dalam pengajaran maupun dunia nyata (Hartono, Firdaus, \& Supriyanti, 2019). Untuk melihat kemampuan representasi yang dimiliki peserta didik dapat dilihat dari bagaimana menyajikan kembali notasi, simbol, tabel, grafik, diagram persamaan atau ekpresi matematis serta kata-kata kedalam bentuk lain (Lestari \& Yudhanegara, 2015).

Kemampuan representasi peserta didik Sekolah Menengah Pertama masih tergolong rendah pada representasi ekpresi matematis dan kata-kata atau teks tertulis yaitu dengan persentase rata-rata 38,9\% dan 23,3\% (Ramanisa, Khairudin, \& Netti, 2020). Kondisi di lapangan ini menunjukkan bahwa proses pembelajaran peserta didik belum sepenuhnya atau relatif kurang menggunakan kemampuan representasi dalam menyelesaikan permasalahan. Hal ini diperkuat dengan hasil wawancara yang dilakukan dengan guru matematika di SMP Negeri 16 Palembang yang didapat informasi bahwa peserta didik kurang dalam mengembangkan rumus, mereka hanya mengerjakan soal sesuai dengan contoh yan diberikan dan jika terdapat sedikt perbedaan maka mengalami kebingungan.

Oleh karena itu perlunya menganalisis kemampuan representasi matematis peserta didik SMP Negeri 16 Palembang dengan tujuan untuk mengetahui kategori kemampuan representasi matematis peserta didik SMP Negeri 16 Palembang.

\section{METODE PENELITIAN}

Penelitian ini adalah penelitian deskriptif dengan tujuan untuk mengetahui kategori kemampuan representasi matematis peserta didik. 
DOI: https://doi.org/10.24127/ajpm.v10i2.3365

Penelitian ini dilakukan pada September 2020 sampai Oktober 2020 di SMP Negeri 16 Palembang. Subjek dalam penelitian ini adalah 30 peserta didik kelas IX.2 yang terdiri dari 14 laki-laki dan 16 perempuan.

Pengumpulan data dalam penelitian ini meliputi tes, wawancara, dan dokumentasi. Tes adalah sebagai teknik utama untuk mengetahui kemampuan representasi matematis siswa. Instrumen tes yang digunakan berupa 4 soal uraian materi sitem persamaan linear dua variabel (SPLDV) yang sudah divalidasi oleh dua dosen matematika dan satu guru matematika. Hasil uji validitas dan reliabilitas pada soal tersebut didapatkan $r_{\text {hitung }}$ uji validitas sebesar 0,72 untuk butir Soal 1, sebesar 0,83 untuk butir Soal 2, sebesar 0,81 untuk butir Soal 3, dan sebesar 0,71 untuk butir Soal 4 . Perhitungan hasil uji reliabilitas didapatkan $r_{\text {hitung }}$ sebesar 0,64 dengan taraf signifikan $5 \%$ dengan banyak sampel 20 dan $r_{\text {tabel }}=0,44$. Dengan demikian, hasil tersebut menunjukkan bahwa ke-empat soal tersebut valid dan reliabel ( $\left.r_{\text {hitung }}>r_{\text {tabel }}\right)$.

Wawancara hanya dipilih 3 peserta didik perwakilan untuk diminta konfirmasi terhadap representasi matematis secara lisan. Ketiga peserta didik tersebut dikodekan dengan p-5, p10, dan $\mathrm{p}-23$. Wawancara kepada guru dilakukan untuk mengetahui kemampuan representasi awal peserta didik. Dokumentasi dalam penelitian ini berupa penilaian dan telaah dokumen hasil jawaban peserta didik pada posttest kemampuan representasi matematis.
Analisis
data
dilakukan menggunakan statistik deskriptif dengan menentukan persentase dan rata-rata. Persentase digunakan untuk menghitung taraf kemampuan representasi matematis dengan perhitungan yang diadaptasikan dari rumus yang dikemukakan oleh Kunandar (2011).

$$
\mathrm{KK}=\frac{\text { Skor Perolehan }}{\text { Skor Maksimal }} \times 100 \%
$$

dengan:

$\mathrm{KK}=$ Persentase kemampuan representasi matematis

Untuk memastikan kebenaran data yang terkumpul, dilakukan triangulasi teknik. Triangulasi teknik dilakukan dengan mengecek data dari sumber yang sama dengan cara yang berbeda (Mawaddah \& Mahmudi, 2021). Dalam hal ini menggunakan teknik tes, wawancara dan dokumentasi.

Kemampuan representasi matematis yang digunakan dalam penelitian ini terdiri dari 3 indikator kemampuan representasi matematis dapat dilihat pada Tabel 1.

Tabel 1. Indikator kemampuan representasi matematis

\begin{tabular}{cll}
\hline No & \multicolumn{1}{c}{ Aspek } & \multicolumn{1}{c}{ Bentuk-bentuk operasional } \\
\hline 1 & Representasi & a. Menggunakan representasi visual untuk menyelesaikan masalah \\
& Visual & b. Membuat diagram, gambar untuk memperjelas masalah dan \\
& & \multicolumn{2}{c}{$\begin{array}{l}\text { memfasilitasi hasilnya } \\
2\end{array}$} & Representasi & a. Membuat persamaan atau model matematis dari representasi \\
& $\begin{array}{l}\text { Ekspresi } \\
\text { Matematis }\end{array}$ & \multicolumn{1}{c}{ lain yang diberikan. } \\
Representasi Kata- & b. Penyelesaian masalah dengan melibatkan ekspresi matematis \\
kata atau Teks & a. Menuliskan interpretasi dari suatu representasi. \\
& Tertulis & b. Menjawab soal dengan menggunakan kata-kata atau teks \\
tertulis.
\end{tabular}

(Kusmaryono \& Dwijanto, 2016) 
Kemudian untuk mengklasifikasikan hasil tes kemampuan representasi matematis peserta didik disajikan pada Tabel 2.

Tabel 2. Klasifikasi hasil nilai tes kemampuan representasi matematis peserta didik

\begin{tabular}{cc}
\hline $\begin{array}{c}\text { Persentase } \\
\text { Pencapaian }\end{array}$ & Kategori \\
\hline $90 \leq \mathrm{KK} \leq 100$ & Sangat Tinggi \\
$75 \leq \mathrm{KK}<90$ & Tinggi \\
$55 \leq \mathrm{KK}<75$ & Sedang \\
$40 \leq \mathrm{KK}<55$ & Rendah \\
$\mathrm{KK}<40$ & Sangat Rendah \\
\hline (Kusmaryono \& Dwijanto, 2016)
\end{tabular}

\section{HASIL DAN PEMBAHASAN}

Hasil kemampuan representasi matematis peserta didik didasarkan dari hasil tes, wawancara dan dokumentasi kemampuan representasi matematis peserta didik. Hasil tes kemampuan representasi matematis peserta didik disajikaan pada Tabel 3.

Tabel 3. Statistik deskriptif kemampuan representasi matematis

\begin{tabular}{ccc}
\hline Statistik & Hasil & Kategori \\
\hline $\mathrm{N}$ & 30 & \multirow{2}{*}{ Sedang } \\
$\bar{x}$ & 62,66 & \\
\hline
\end{tabular}

Berdasarkan Tabel 3 didapat bahwa kemampuan representasi siswa secara keseluruhan termasuk dalam kategori sedang. Selain didapat hasil rata-rata kemampuan representasi peserta didik secara keseluruhan, didapat juga perhitungan rata-rata jawaban peserta didik tiap indikator sebagaimana disajikan Tabel 4.

Berdasarkan Tabel 4 terlihat bahwa meskipun peserta didik memiliki kemampuan tinggi pada aspek representasi ekspresi matematis, namun memiliki kemampuan rendah pada aspek representasi visual dan kemampuan sangat rendah pada aspek representasi kata-kata atau teks tertulis. Hal ini menunjukkan bahwa meskipun peserta didik mampu menyelesaikan masalah yang melibatkan ekspresi matematis dengan membuat persamaan atau model matematis dan menyelesaikan perhitungan, namun peserta didik masih kesulitan dalam menggambarkan grafik penyelesaian pada soal dan menginterpretasikannya.

Tabel 4. Nilai rata-rata kemampuan representasi matematis

\begin{tabular}{|c|c|c|}
\hline Aspek & $\begin{array}{c}\text { Rata- } \\
\text { rata }(\%)\end{array}$ & Kategori \\
\hline $\begin{array}{l}\text { Representasi } \\
\text { Visual }\end{array}$ & 43,33 & Rendah \\
\hline $\begin{array}{l}\text { Representasi } \\
\text { Ekpresi } \\
\text { Matematis }\end{array}$ & 80,37 & Tinggi \\
\hline $\begin{array}{l}\text { Representasi } \\
\text { Kata-kata atau } \\
\text { Teks Tertulis }\end{array}$ & 28,89 & $\begin{array}{l}\text { Sangat } \\
\text { Rendah }\end{array}$ \\
\hline
\end{tabular}

Data untuk masing-masing kategori kemampuan representasi matematis peserta didik SMP Negeri 16 Palembang dianalisis berdasarkan indikator kemampuan representasi matematis dalam menyelesaikan soal yang telah diberikan. Hal ini perlu dilakukan untuk mengetahui kemampuan representasi matematis peserta didik secara mendalam. Perbedaan cara menjawab yang dilakukan peserta didik bedasarkan masing-masing indikator kemampuan representasi matematis dideskripsikan sebagai berikut.

1) Kemampuan Representasi Visual

Soal yang memperlihatkan representasi visual untuk menyelesaikan permasalahan yaitu Soal 2b. Contoh jawaban peserta didik dalam menggunakan representasi visual dilihat pada Gambar 1. 
DOI: https://doi.org/10.24127/ajpm.v10i2.3365

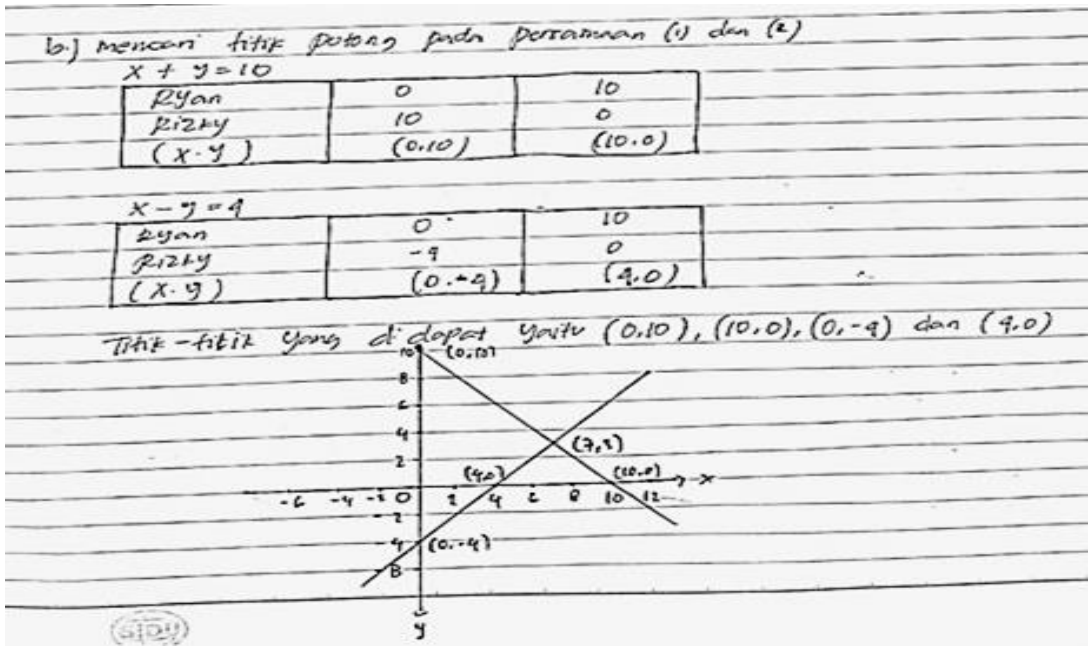

Gambar 1. Jawaban peserta didik indikator representasi visual skor 3

didik $\begin{gathered}\text { Berdasarkan Gambar } 1 \text { peserta } \\ \text { yang menjawab }\end{gathered}$ mendapatkan Skor 3 terlihat mampu membuat gambar grafik dengan lengkap dan benar untuk menyelesaikan permasalahan. Ketepatan menentukan titik potong dan menggambarkan garis lurus dari sebuah persamaan. Terlihat peserta didik sudah memahami cara membuat koordinat kartesius untuk menentukan titik pada grafik dan memahami konsep bilangan bulat serta garis bilangan untuk menggambarkan sumbu $x$ dan sumbu $y$. Selanjutnya analisis jawaban dengan Skor 2 Soal $2 b$ dapat dilihat pada Gambar 2.

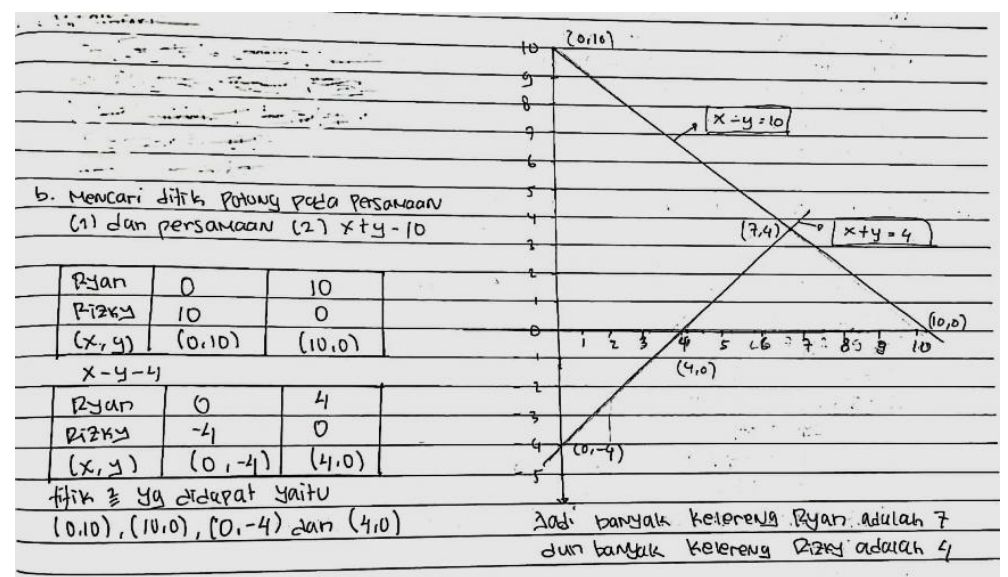

Gambar 2. Jawaban peserta didik indikator representasi visual skor 2

Pada jawaban peserta didik dengan mendapat Skor 2 dalam menjawab Soal $2 b$ terdapat kesalahan peserta didik dalam menjawab yaitu menggambarkan titik pada sumbu $x$ dan sumbu $y$ yang memiliki jarak antar bilangan tidak sama. Sehingga pertemuan titik potong yang benar adalah $(7,3)$ tetapi hasil jawaban peserta didik yang didapat yaitu $(7,4)$. Hal ini menunjukkan peserta didik belum memahami materi prasyarat garis bilangan. Berikutnya, analisis jawaban dengan Skor 1 Soal 2b dapat dilihat pada Gambar 3. 
DOI: https://doi.org/10.24127/ajpm.v10i2.3365

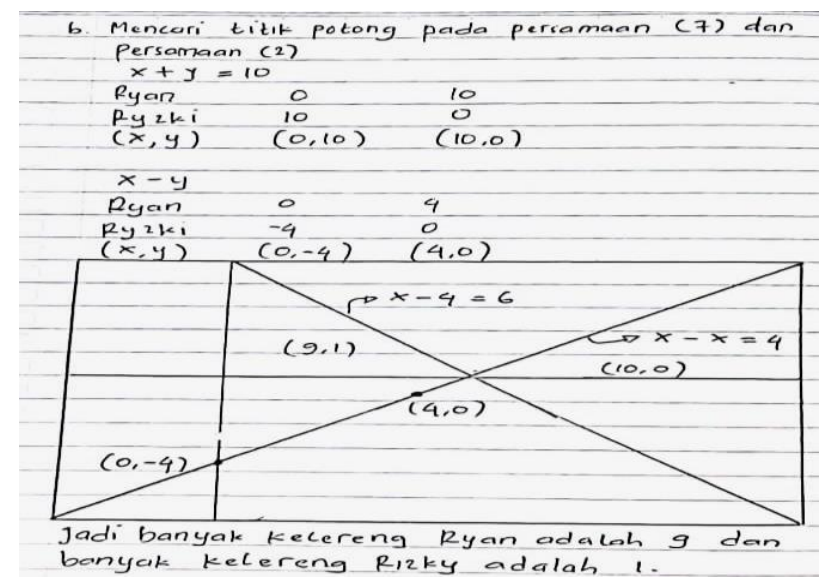

Gambar 3. Jawaban peserta didik indikator representasi visual skor 1

Pada jawaban peserta didik yang mendapat Skor 1, dalam menjawab Soal $2 \mathrm{~b}$ terdapat kesalahan dalam menjawab. Kesalahan tersebut yaitu menggambarkan grafik penyelesaian pada soal. Terlihat jawaban peserta didik yang hanya menggambarkan dua garis lurus saling berpotongan dan tidak membuat garis bilangan pada koordinat kartesius. Artinya, peserta didik tidak mampu menggambarkan koordinar kartesius dan belum memahami konsep garis bilangan. Selanjutnya, analisis jawaban peserta didik dengan Skor 0 Soal $2 b$ disajikan Gambar 4.

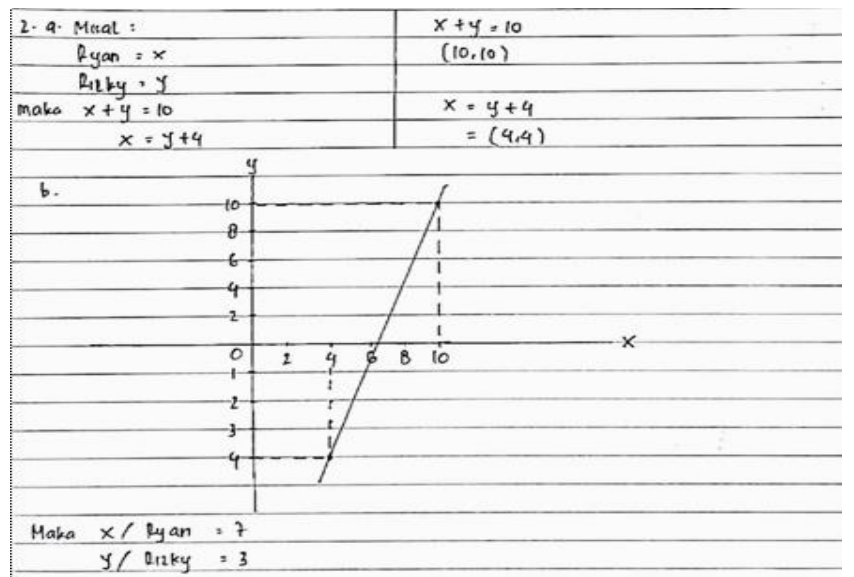

Gambar 4. Jawaban peserta didik indikator representasi visual skor 0

Berdasarkan Gambar 4 peserta didik yang mendapat Skor 0 hanya memperlihatkan jawaban ketidak pahaman tentang konsep. Hal ini terlihat peserta didik yang tidak mampu menentukan titik potong dari sebuah persamaan, menggambarkan garis bilangan yang skala penomoran tidak sama tetapi mampu menggambarkan persamaan sebuah garis melalui titik potong walaupun titik tersebut salah. Hal ini menunjukkan bahwa materi prasyarat itu sangat penting bagi materi yang akan dipelajari selanjutnya.

Berdasarkan jawaban peserta didik dalam menjawab Soal $2 b$ terlihat kesalahan terbanyak peserta didik adalah menentukan titik potong dan menggambarkan titik pada koordinat katesius. Sebagian besar peserta didik 
DOI: https://doi.org/10.24127/ajpm.v10i2.3365

menggambarkan jarak pada setiap titik koordinat kartesius tidak sama sehingga tidak tepat dalam menentukan titik potongnya. Ini artinya peserta didik tidak memahami cara membuat koordinat kartesius, tidak memahami konsep bilangan bulat serta garis bilangan untuk menggambarkan sumbu $x$ dan sumbu $y$.

Pada Soal 2b indikator representasi visual, peserta didik yang mendapatkan Skor 3 sebanyak 8 orang, Skor 2 sebanyak 2 orang, Skor 1 sebanyak 11 orang dan 0 sebanyak 9 orang. Berdasarkan hasil tersebut sebagian besar peserta didik mendapat Skor 0 dan 1 yang artinya kemampuan peserta didik menyelesaikan permasalahan menggunakan representasi visual belum maksimal.

2) Kemampuan Representasi Ekpresi Matematis

Soal yang memperlihatkan bagaimana kemampuan representasi matematis peserta didik yaitu pada Soal 1, 2a dan 4. Berikut contoh jawaban peserta didik menjawab menggunakan representasi ekpresi matematis dilihat pada Gambar 5.

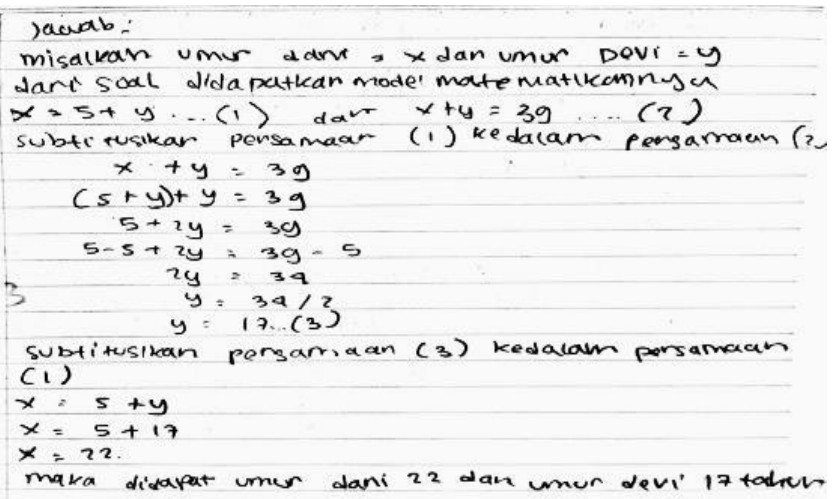

Gambar 5. Jawaban peserta didik indikator representasi ekspresi matematis skor 3

Pada Gambar 5 peserta didik yang mendapat Skor 3 mampu menggunakan representasi ekpresi matematis dengan baik. Mampu membuat permisalan, membuat model matematika, melakukan perhitungan dan menentukan solusi akhir dengan benar. Selanjutnya, hasil jawaban dengan Skor 2 dapat dilihat pada Gambar 6.

\begin{tabular}{|c|c|}
\hline \multicolumn{2}{|l|}{ 9. Mral: } \\
\hline Umur Dani $=x$ & sultenican paracucan (3) ke pus (4) \\
\hline Unew $D_{\text {ex }}=y$ & $x \cdot 5+y^{\prime}$ \\
\hline Model Makine tikanya. & $x=15+17$ \\
\hline$x=5+y \quad \cdots(1)$ & $x, 21$ \\
\hline$x+y=3, \cdots(2)$ & \\
\hline 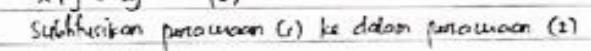 & Umur Deni 17 das Desi iz tahen. \\
\hline $\begin{array}{l}x+y=39 \\
(5+y)+y=39\end{array}$ & \\
\hline $5+2 y=39$ & \\
\hline $5 \cdot 5+2 y=29 \cdot 5$ & \\
\hline $2 y=34$ & \\
\hline$y=\frac{34}{2}$ & \\
\hline$y=A \cdot \overline{2}(x)$ & \\
\hline
\end{tabular}

Gambar 6. Jawaban peserta didik indikator representasi ekspresi matematis skor 2 
DOI: $\underline{\text { https://doi.org/10.24127/ajpm.v10i2.3365 }}$

Peserta didik mendapatkan Skor 2 juga mampu membuat permisalan, model matematika dan melakukan perhitungan dengan benar. Kesalahan yang dilakukan peserta didik yang mendapat Skor 2 yaitu menentukan solusi terakhir dalam penyelesaian umur Dani dan Devi yang keliru. Hal ini disebabkan kurang telitinya peserta didik dalam mengerjakan soal. Contoh jawaban peserta didik dengan Skor 0 dapat dilihat pada Gambar 7.

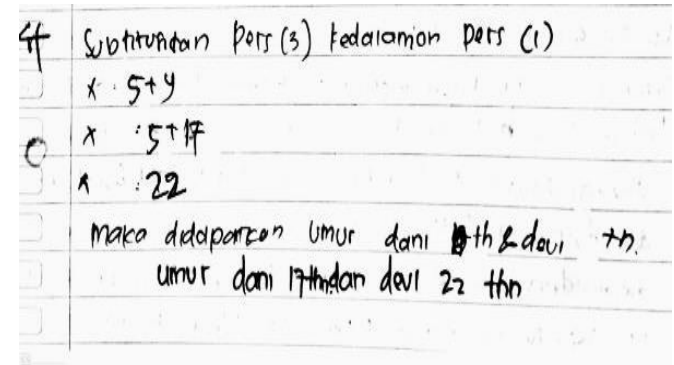

Gambar 7. Jawaban peserta didik indikator representasi ekspresi matematis skor 0

Berdasarkan Gambar 7, Skor 0 diberikan karena hasil jawaban peserta didik hanya memperlihatkan jawaban yang tidak berarti. Artinya peserta didik dianggap tidak paham konsep.

Berdasarkan jawaban peserta didik dalam menjawab terlihat sebagian besar peserta didik salah dalam menentukan solusi terakhir penyelesaian. Hal ini dikarenakan peserta didik tidak melihat permisalan diawal sehingga terjadi kekeliruan. Penyebab kekeliruan tersebut dikarenakan peserta didik belum paham kegunaan membuat permisalan diawal pengerjaan.

Pada soal yang mengukur representasi ekpresi matematis, peserta didik yang mendapat Skor 3 sebanyak 44 (sebanyak 12 Soal 1, 25 Soal 2a dan 7 Soal 4), Skor 2 sebanyak 42 (sebanyak 17 Soal 1, 4 Soal 2a, dan 21 Soal 4), Skor 1 sebanyak 1 (Soal 1) dan Skor 0 sebanyak 3 (sebanyak 1 Soal 2a dan 2 Soal 4). Berdasarkan rincian skor representasi ekpresi matematis, Skor 3 dan Skor 2 adalah skor yang mendominan dalam representasi ekpresi matematis. Hal ini menunjukkan penyelesaian masalah menggunakan representasi ekpresi matematis lebih baik.

3) Kemampuan Representasi Katakata atau Teks Tertulis

Mengukur bagaimana kemampuan representasi kata-kata atau teks tertulis dapat dilihat dari peserta didik menjawab Soal 3. Berikut contoh jawaban peserta didik dalam menjawab Soal 3 yang disajikan pada Gambar 8 .

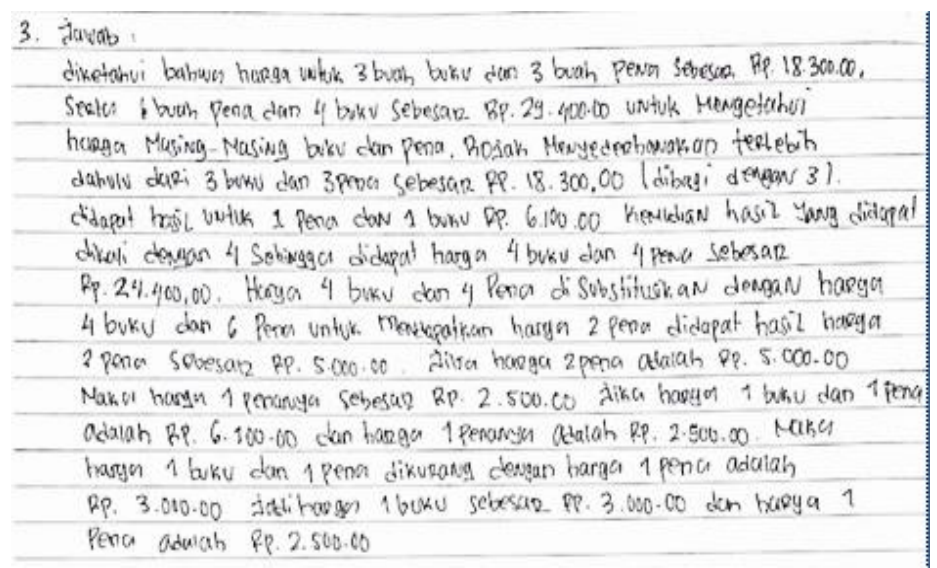

Gambar 8. Jawaban peserta didik indikator representasi kata-kata atau teks tertulis skor 2 
DOI: https://doi.org/10.24127/ajpm.v10i2.3365

Berdasarkan Gambar 8 terlihat bahwa kesalahan peserta didik yang mendapat Skor 2 yaitu terjadi pada langkah menentukan harga 2 buah pena, yang seharusnya peserta didik menjelaskan bahwa Rojak mengeliminasi persamaan $4 \mathrm{x}+4 \mathrm{y}=\mathrm{Rp}$ $24.400,00$ dengan persamaan $6 x+4 y$ $=29.400,00$ akan tetapi peserta didik menjelaskan dengan mensubtitusikannya. Selain itu, kesalahan juga terdapat saat menentukan harga 1 buah buku. Peserta didik menjelaskan untuk mendapatkan harga 1 buah buku yaitu mengurangkan harga 1 buah buku dan 1 buah dengan 1 buah pena didapat harga 1 buah buku Rp 3.000,00. Seharusnya untuk mendapatkan harga 1 buah buku yaitu dengan cara mensubtitusikan harga 1 buah pena $\mathrm{Rp} 2.500,00$ pada harga 1 buah buku dan 1 buah pena $\mathrm{Rp}$ 6.100,00 didapat harga 1 buah buku Rp $3.600,00$. Contoh jawaban peserta didik dengan skor 1 Soal 3 dapat dilihat pada Gambar 9.

\begin{tabular}{|c|c|}
\hline 3 & 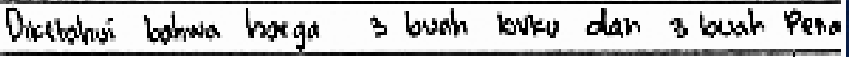 \\
\hline$\square$ & Re 18. 300.00 sesto hargo 6 buah pera dan 4 bua \\
\hline- & buev lp 29.400.00. Unhuk mengtakvi hatga masing \\
\hline$\perp$ & 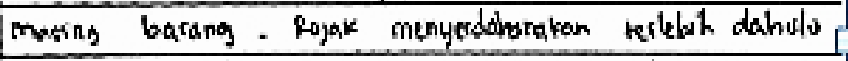 \\
\hline & 1 Rerian dar 1 borku RP 6.100 .00 , 3 buah tena \\
\hline & 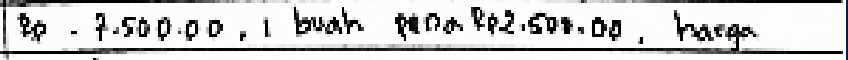 \\
\hline & Re. 300.600 .00 \\
\hline
\end{tabular}

Gambar 9.Jawaban peserta didik indikator representasi kata-kata atau teks tertulis skor 1

Gambar 9 di atas menunjukkan hasil jawaban peserta didik dengan Skor 1 Soal 3 pada indikator representasi kata-kata atau teks. Diberikan Skor 1 dikarenakan peserta didik hanya menuliskan apa yang diketahui saja. Peserta didik belum mampu menuliskan kembali strategi yang digunakan Rojak dalam menentukan harga 1 buku dan 1 pena. Selain itu terlihat jawaban peserta didik yang tidak logis dengan menuliskan apa yang diketahui dalam soal kemudian didapatkan hasil 1 buah pena $\mathrm{Rp} 2.500,00$ dan harga 1 buku $\mathrm{Rp}$ 3.600,00. Berikut contoh jawaban peserta didik dengan Skor 0 disajikan pada Gambar 10.

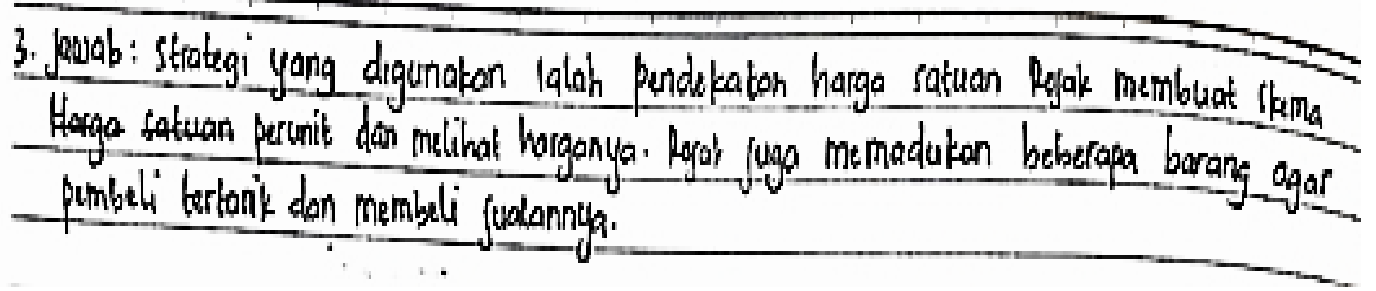

Gambar 10. Jawaban peserta didik indikator representasi kata-kata atau teks tertulis skor 0

Selanjutnya, hasil jawaban peserta didik dengan Skor 0 pada Soal 3 dapat dilihat pada Gambar 10 di atas. Peserta didik yang mendapat Skor 0 menuliskan jawaban yang memperlihatkan ketidakpahamannya tentang konsep. Terlihat hanya menuliskan jawaban yang tidak memperlihatakan strategi yang digunakan Rojak dalam menentukan 
harga 1 buku dan 1 pena. Hal ini menunjukkan peserta didik belum mampu menginterpretasikan permasalahan kedalam bentuk kata-kata atau teks tertulis.

Berdasarkan jawaban peserta didik dalam mengerjakan Soal 3, sebagian besar peserta didik tidak dapat menyatakan kembali strategi yang digunakan kedalam bentuk kata-kata atau teks tertulis. Artinya peserta didik dianggap relatif kurang dalam menyelesaikan masalah menggunakan representasi kata-kata atau teks tertulis.

Pada Soal 3 yaitu soal yang mengukur representasi kata-kata atau teks tertulis, peserta didik yang mendapat Skor 2 sebanyak 8, Skor 1 sebanyak 10, Skor 0 sebanyak 12. Berdasarkan rincian skor representasi kata-kata atau teks tertulis, Skor 0 adalah skor yang mendominan dalam representasi kata-kata atau teks tertulis. Hal ini menunjukkan penyelesaian masalah menggunakan representasi kata-kata atau teks tertulis belum maksimal.

Proses mengungkapkan ide ke bentuk simbol, gambar, diagram dan kata-kata dalam permasalahan matematika tidak langsung didapatkan oleh peserta didik. Pengungkapan ide tersebut harus melalui pembelajaran yang membutuhkan waktu. Pada penelitian ini indikator kemamampuan representasi matematis visual diperoleh persentase rata-rata sebesar 43,33. Berdasarkan kategori pada Tabel 2 representasi visual termasuk kedalam kategori rendah. Skor penilaian yang mendominasi pada representasi visual yaitu Skor 0 dan 1. Sehingga pada indikator ini peserta didik belum mampu menggambarkan diagram grafik dengan benar. Hal ini terlihat pada jawaban peserta didik yang tidak dapat menentukan titik potong persamaan pada soal dan tidak dapat menggambarkan titik pada koordinat kartesius.

Pada indikator kemampuan representasi ekpresi matematis peserta didik memperoleh persentase rata-rata sebesar 80,37 termasuk dalam kategori tinggi. Skor 3 dan 2 merupakan skor yang mendominasi pada representasi ekpresi matematis. sehingga pada indikator representasi ekpresi matematis peserta didik mampu menyelesaikan permasalahan dengan membuat permisalan, model matematika dan menyelesaikan perhitungan. Akan tetapi dalam menenentukan solusi terakhir terdapat kekeliruan. Kekeliruan ini disebabkan oleh tidakpahamnya peserta didik dengan permisalan diawal. Penelitian ini sejalan dengan penelitian terdahulu oleh Ummul, Edwin, dan Nola (2019) yang berjudul "Analisis Kemampuan Representasi Siswa dalam Menyelesaikan Soal Pemecahan Masalah Matematis" bahwa pada representasi ekpresi matematis peserta didik sudah mampu membuat model matematika dan menyelesaikan ekpresi dengan baik, tetapi masih kurang teliti dalam mengerjakan soal hal ini terlihat berdasarkan kekeliruan peserta didik dalam menyelesaikan soal tahap terakhir.

Pada indikator kemampuan representasi kata-kata atau teks tertulis peserta didik termasuk kedalam kategori sangat rendah dengan persentase ratarata sebesar 28,89. Skor yang mendominan dalam representasi matematis yaitu 0 dan 1 . Artinya peserta didik belum mampu mengubah permasalahan matematika kedalam bentuk kata-kata atau teks tertulis. Peserta didik hanya menuliskan apa yang diketahui dalam soal. Hal ini disebabkan peserta didik tidak terbiasa mengerjakan soal yang disertai dengan 
DOI: https://doi.org/10.24127/ajpm.v10i2.3365

perintah menuliskan strategi penyelesaian secara tertulis (Sutrisno, Sudargo, \& Titi, 2019). Hal selanjutnya yang dilakukan adalah mengkonfirmasi hasil jawaban post-test peserta didik terhadap peserta didik yang bersangkutan dengan melakukan wawancara.

Hasil wawancara menunjukkan 2 dari 3 peserta didik yang diwawancara mengaku sulit dalam menginterpretasikan gagasan kedalam bentuk visual. Hasil analisis dokumen post-test dalam menyelesaikan soal kemampuan representasi matematis diketahui bahwa masih ada siswa yang belum mampu menggambarkan koordinat kartesius dan belum memahami konsep garis bilangan. temuan ini sejalan dengan pendapat Pasehah dan Firmansyah (2019) bahwa siswa kategori rendah tidak terdapat jawaban walaupun ada hanya memperlihatkan tentang tidak pahamnya suatu konsep.

Hasil wawancara menunjukkan 2 dari 3 peserta didik masih kesulitan dalam menginterpretasikan masalah kedalam bentuk kata-kata atau teks secara runtut. Hal ini dikarenakan peserta didik terbiasa menuliskan rumus dan hasil jawaban yang singkat. Temuan ini sejalan dengan Ariani (2017) bahwa kesulitan siswa dalam penyelesaian masalah matematis karena rendahnya kemampuan menulis gagasan matematis.

Berdasarkan hasil dokumentasi jawaban post-test dan wawancara bahwa peserta didik dalam membuat persamaan atau model matematika untuk menyelesaikan suatu permasalahan terklasifikasi dalam kategori tinggi dengan persentase ratarata 80,37. Pada indikator representasi visual peserta didik termasuk dalam kategori rendah dengan persentase rata- rata 43,33. Hasil temuan penelitian ini bertentangan dengan pendapat Ramanisa, Khairudin, \& Netti (2020) yang menyatakan bahwa persentase pada representasi ekpresi matematis sebesar 38,9 dan representasi visual sebesar 82,7. Perbedaan temuan ini didasarkan pada kesulitan yang dialami peserta didik saat belajar berupa pemahaman konsep yang kurang, penguasaan materi prasyarat yang belum baik, dan kurang teliti peserta didik dalam mengerjakan soal (Sutrisno \& Murtianto, 2016). Selain itu, kecenderungan peserta didik yang lebih mampu menyelesaikan permasalahan representasi visual dan ekpresi matematis dipengaruhi representasi yang diajarkan guru pada saat memberikan materi yang sedang diajarkan (Astuti \& Siroj, 2017).

Dari penelitian ini didapatkan implikasi bahwa tidak semua peserta didik mampu menyelesaikan permasalahan dengan menggunakan ketiga indikator tersebut dengan benar. Hal ini ditunjukkan dengan kesalahan peserta didik dalam menyelesaikan soal. Peserta didik perlu berlatih mengerjakan soal menggunakan representasi dan perlunya meningkatkan kuantitas dan kualitas soal penyelesaian masalah yang diberikan kepada peserta didik.

\section{KESIMPULAN DAN SARAN}

Berdasarkan hasil analisis dan pembahasan didapat kesimpulan bahwa kemampuan representasi matematis peserta didik secara keseluruhana terklasifikasi dalam kategori sedang. Pada tiap indikator didapat indikator representasi visual terklasifikasi dalam kategori rendah. Kemudian indikator representasi ekpresi matematis terklasifikasi dalam kategori tinggi. Serta indikator representasi kata-kata 
atau teks tertulis terklasifikasi dalam kategori sangat rendah.

Tidak semua peserta didik mampu menyelesaikan permasalahan dengan menggunakan ketiga indikator tersebut dengan benar, oleh karena itu peserta didik perlu berlatih mengerjakan soalsoal dengan menggunakan representasi, supaya terlatih dalam mengerjakan soal yang menggunakan kemampuan representasi. Selain itu, perlu dilakukannya penelitian lanjutan dalam meningkatkan kemampuan representasi matematis peserta didik terutama pada representasi kata-kata atau teks tertulis dan representasi visual.

\section{DAFTAR PUSTAKA}

Ariani, D. N. (2017). Strategi Peningkatan Kemampuan Komunikasi Matematis Siswa SD/MI. Muallimuna : Jurnal Madrasah Ibtidaiyah 3(1), 96107.

Astuti, R., \& Siroj, R. A. (2017). Analisis Kemampuan Representasi Siswa dalam Menyelesaikan Soal Matematika. Prosiding Seminar Nasioanal Pendidikan (pp. 512521). Palembang: Universitas Muhammadiyah Palembang.

Hartono, Firdaus, M., \& Supriyanti. (2019).

Kemampuan

Representasi Matematis dalam Materi Fungsi dengan Pendekatan Open Ended Siswa Kleas VII MTS Sirajul Ulum Pontianak. Jurnal Eksponen 9(1), 9-20.

Kunandar. (2011). Langkah Mudah Penelitian Tindakan Kelas Sebagai Pengembangan Profesi Guru. Jakarta: Grafindo Persada.

Kurniawan, D., \& Kartono. (2018). Peran Demonstration Feedback dalam Pembelajaran Group
Investigation Berintegrasi

Pendidikan Karakter pada

Pencapaian Kemampuan

Representasi Matematis berdasar

Self-efficacy. Seminar Nasional

Pendidikan Matematika Ahmad

Dahlan (pp. 585-593).

Yogyakarta: Universitas Ahmad

Dahlan.

Kusmaryono, I., \& Dwijanto. (2016).

Peranan Representasi dan

Disposisi Matematis Siswa

terhadap Peningkatan

Mathematical Power. JIPMat 1(1), 19-28.

Latif, S., \& Akib, I. (2016). Mathematical Connection Ability in Solving Mathematics Problem Based on Initial Abilities of Students at SMPN 10 Bulukumba. Daya Matematis 4(2), 207-2017.

Lestari, K. E., \& Yudhanegara, M. R. (2015). Penelitian Pendidikan Matematika. Bandung: Refika Aditama.

Mawaddah, S., \& Mahmudi, A. (2021). Analisis Kemampuan Komunikasi Matematika Siswa Melalui Penggunaan ProjectBased Learning Terintegrasi Stem. Aksioma 10(1), 167-182.

Pasehah, A. M., \& Firmansyah, D. (2019). Analisis Kemampuan Representasi Matematis Siswa pada Materi Penyajian Data. Prosiding Seminar Nasional Matematika dan Pendidikan Matematika Sesiomadika (pp. 1094-1108). Karawang: Universitas Singaperbangsa Karawang.

Ramanisa, H., Khairudin, \& Netti, S. (2020). Analisis Kemampuan Representasi Matematis. Jumadika 2(1), 34-38. 
DOI: https://doi.org/10.24127/ajpm.v10i2.3365

Sari, I. J., \& Sari, A. (2019). Pengaruh Penerapan Model Pembelajaran Think Pair Share terhadap Kemampuan Representasi Matematis ditinjau dari Kemampuan Awal Matematis Siswa. Juring 2(3), 191-198.

Sutrisno, \& Murtianto, Y. H. (2016). Miskonsepsi Mahasiswa pada Mata Kuliah Statistik Deskriptif Materi Ukuran Tendensi Sentral, Ukuran Dispersi, dan Ukuran Letak. Media Penelitian Pendidikan 10(1), 1-14.

Sutrisno, Sudargo, \& Titi, R. A. (2019). Analisis Kemampuan Representasi Matematis Siswa SMK Kimia Industri Theresiana Semarang. Jurnal Ilmiah Pendidikan Matematik 4(1), 6576.

Ummul, H., Edwin, M., \& Nola, N. (2019). Analisis Kemampuan Representasi Matematis Siswa dalam Menyelesaikan Soal Pemecahan Masalah Matematika. TA'DIB 22(1), 1926.

Wijayanti, D. A., \& Deniyanti, P. (2020). Pengaruh Penerapan Model Pembelajaran Means Ends Analysis terhadap Kemampuan Menalar Deduktif Siswa ditinjau dari Kemampuan Representasi Matematis Siswa. Medives 4(1), 151-160. 